\title{
HUBUNGAN KETEPATAN PEMILIHAN ANTIBIOTIK EMPIRIS DENGAN OUTCOME TERAPI PADA PASIEN SEPSIS DI INSTALASI RAWAT INAP BEBERAPA RUMAH SAKIT
}

\author{
Gita Rizqi Ramita*, Sabaniah Indjar Gama, Adam M.Ramadhan \\ Laboratorium Penelitian dan Pengembangan Kefarmasian "Farmaka Tropis", \\ Fakultas Farmasi, Universitas Mulawarman, Samarinda, Indonesia \\ *Email: gitarizqiramita@gmail.com
}

\begin{abstract}
Antibiotic therapy is one of the supporting components in the successful treatment of sepsis. One of the therapy for sepsis is using empirical antibiotics. The empirical antibiotics used must be rational, adequate and appropriate to avoid resistance. The purpose of this study was to determine patient characteristics, empirical antibiotic selection patterns, patterns of sensitivity and bacterial resistance to antibiotics, the accuracy of empirical antibiotic selection, and the relationship between the accuracy of empirical antibiotic selection and treatment outcomes. This study was an observational study using retrospective data collection, then analyzed descriptively, with inclusion criteria being diagnosed with sepsis, adulthood, hospitalization of Abdul Wahab Sjahranie Samarinda hospital and AM Parikesit Tenggarong from January to December 2017. The results showed empirical antibiotics Ceftriaxone used a sensitivity value of $26.67 \%$ and Meropenem sensitivity value of $16.67 \%$. The accuracy of antibiotics based on bacterial sensitivity test shows an accuracy percentage of $61.90 \%$. The results of the statistical analysis showed that there was a correlation between the accuracy of empirical antibiotic selection in septic patients and treatment outcomes ( $p<0.05)$.
\end{abstract}

Keywords: Sepsis, empirical antibiotics, outcome of therapy

\begin{abstract}
ABSTRAK
Terapi antibiotik merupakan salah satu komponen penunjang dalam keberhasilan pengobatan sepsis. Salah satu terapi sepsis yaitu menggunakan antibiotik empiris. Antibiotik empiris yang digunakan harus rasional, adekuat dan tepat untuk menghindari terjadinya resistensi. Tujuan penelitian ini adalah mengetahui karakteristik pasien, pola pemilihan antibiotik empiris, pola sensitivitas dan resistensi bakteri terhadap antibiotik, ketepatan pemilihan antibiotik empiris, dan hubungan ketepatan pemilihan antibioktik empiris dengan outcome terapi. Penelitian ini adalah penelitian observasional dengan cara pengambilan data secara retrospektif, kemudian dianalisis secara deskriptif, dengan kriteria inklusi adalah diagnosa sepsis, usia dewasa, dirawat inap rumah sakit Abdul Wahab Sjahranie Samarinda dan A.M Parikesit Tenggarong periode Januari-Desember 2017. Hasil penelitian menunjukkan antibiotik empiris yang digunakan adalah Ceftriaxone nilai sensitivitas sebesar 26,67\% dan Meropenem nilai sensitivitas sebesar 16,67\%. Ketepatan antibiotik berdasarkan uji sensitivitas bakteri menunjukkan persentase ketepatan sebesar
\end{abstract}


$61,90 \%$. Hasil analisis statistik menunjukkan bahwa adanya hubungan ketepatan pemilihan antibiotik empiris pada pasien sepsis dengan outcome terapi $(\mathrm{p}<0,05)$.

Kata kunci: Sepsis, antibiotik empiris, outcome terapi

\section{DOI: https://doi.org/10.25026/mpc.v8i1.327}

\section{PENDAHULUAN}

Sepsis adalah sindrom respon inflamasi sistemik (Systemic Inflammatory Respone Syndrome/SIRS) ditambah tempat infeksi yang diketahui (ditentukan dengan biakan positif terhadap organisme dari tempat tersebut). Biakan darah penderita sepsis yang positif di Indonesia berkisar 40-70\%. Secara umum penyebab sepsis terbesar adalah bakteri gram negatif dengan persentase $60-70 \%$ kasus $^{5}$.

Di Amerika Serikat (AS) penyakit sepsis mencapai 660.000 pertahun, peneliti lain menyampaikan angka hingga 750.000 dan 210.000 diantaranya meninggal dunia. Pengobatan total di AS untuk sepsis diperkirakan lebih dari 16 milyar Dollar pertahun. Oleh karena beberapa penjelasan di atas, sehingga penting bagi kita untuk mengetahui dan memahami pengelolaan keadaan tersebut.

Pemberian antibiotik yang tepat menjadi salah satu kriteria pada tata laksana sepsis ${ }^{2}$. Penggunaan antibiotik empiris yang memadai dan tepat waktu adalah landasan pengobatan sepsis disamping optimalisasi awal hemodinamik pasien. Antibiotik empiris adalah penggunaan antibiotik pada kasus infeksi yang jenis bakteri penyebabnya belum diketahui, diharapkan penggunaan antibiotik pada terapi empiris ini dapat menghambat pertumbuhan bakteri yang diduga menjadi penyebab kasus infeksi sebelum diperoleh hasil pemeriksaan mikrobiologi ${ }^{10}$.Terapi antibiotik empiris harus segera dimulai dalam 1-2 jam, jam pertama sepsis ditegakkan, sambil menunggu hasil pemeriksaan kultur.
Keterlambatan dalam pemberian antibiotik dalam waktu 24 jam setelah sepsis ditegakkan berkolerasi kuat dengan meningkatnya kematian dalam kurun waktu 28 hari $^{18}$.

Dengan ketepatan pemilihan antibiotik empiris, maka outcome terapi pasien dapat tercapai. Outcomes adalah hasil terapi yang merupakan tujuan dari pelayanan farmasi untuk meningkatkan atau mencapai kualitas hidup pasien yang lebih baik. Outcomes bertujuan untuk menyembuhkan penyakit pasien, menghilangkan atau pengurangan gejala penyakit pasien, menghambat atau memperlambat proses perkembangan penyakit, dan pencegahan penyakit atau gejala-gejala.

\section{METODE PENELITIAN}

Penelitian ini adalah penelitian observasional dengan cara pengambilan data secara retrospektif, dengan cara pengambilan data teknik purposive sampling, kemudian dianalisis secara statistik.

Populasi adalah pasien sepsis yang dirawat diinstalasi rawat inap periode 2017. Sampel penelitian ini adalah pasien diagnosa sepsis, usia dewasa, dirawat diinstalasi rawat inap periode 2017 , dan mempunyai hasil kultur bakteri.

Pengumpulan data pasien diambil dari rekam medis pasien meliputi, karakteristik pasien (jenis kelamin, usia, pendidikan, dan pekerjaan), jenis bakteri penginfeksi, pola penggunaan pemilihan antibiotik empiris, sensitivitas dan resistensi bakteri dari hasil kultur, 
ketepatan pemilihan antibiotik empiris dan hubungan ketepatan pemilihan antibiotik empiris dengan outcome terapi.

\section{HASIL DAN PEMBAHASAN}

Penelitian ini diperoleh 30 pasien sepsis di instalasi rawat inap di beberapa rumah sakit periode Januari-Desember 2017 dengan karakteristik disajikan pada Tabel 1.

Tabel 1 Data persentase jumlah pasien sepsis berdasarkan karakteristik pasien.

\begin{tabular}{|c|c|c|}
\hline Karakteristik & Jumlah pasien (n) & Persentase $(\%)$ \\
\hline \multicolumn{3}{|l|}{$\frac{\text { Karakteristik }}{\text { Jenis Kelamin }}$} \\
\hline Laki-laki & 13 & 43,33 \\
\hline Perempuan & 17 & 56,67 \\
\hline Jumlah & 30 & 100 \\
\hline \multicolumn{3}{|l|}{ Usia (tahun) } \\
\hline 26-35 tahun & 1 & 3,33 \\
\hline 36-45 tahun & 3 & 10 \\
\hline 46-55 tahun & 5 & 16,67 \\
\hline 56-65 tahun & 14 & 46,67 \\
\hline$>66$ tahun & 7 & 23,33 \\
\hline Jumlah & 30 & 100 \\
\hline \multicolumn{3}{|l|}{ Pendidikan } \\
\hline $\mathrm{SD}$ & 14 & 46,67 \\
\hline SMP & 6 & 20 \\
\hline SMA & 8 & 26,66 \\
\hline S1 & 2 & 6,67 \\
\hline Jumlah & 30 & 100 \\
\hline \multicolumn{3}{|l|}{ Pekerjaan } \\
\hline IRT & 14 & 46,67 \\
\hline Swasta & 8 & 26,66 \\
\hline Buruh & 4 & 13,33 \\
\hline Petani & 2 & 6,67 \\
\hline PNS & 2 & 6,67 \\
\hline Jumlah & 30 & 100 \\
\hline
\end{tabular}

Berdasarkan mengenai karakteristik pasien dengan kelompok jenis kelamin, angka kejadian sepsis lebih banyak terjadi pada perempuan daripada lakilaki. Hal ini terjadi karena adanya gangguan pada kondisi imunologis perempuan sehingga diperkirakan sebagai penyebab tingginya angka kejadian sepsis dan peningkatan mortalitas pada perempuan ${ }^{14}$. Kejadian sepsis pada wanita dihubungkan dengan komplikasi infeksi seperti infeksi saluran kemih, endometritis, luka infeksi dan abortus septis. Infeksi saluran kemih sering dikaitkan sebagai penyebab infeksi, hal ini dikarenakan terjadinya perubahan secara anatomi dan fisiologis sehingga memudahkan ascending infection. Penyakit infeksi saluran kemih yang tidak diatasi dengan serius bisa menyebabkan sepsis, yakni kondisi dimana bakteri masuk ke aliran darah. Jika kondisi tersebut terjadi maka bisa merenggut nyawa penderitanya. Perubahan kimiawi 
urine juga memudahkan pertumbuhan kuman patogen sebagai penyebab infeksi.

Berdasarkan karakteristik pasien dengan kelompok usia, maka usia terbanyak yang terkena sepsis yaitu pada rentang 56-66 tahun (lansia awal) dengan jumlah 14 pasien $(46,67 \%)$, hal ini disebabkan karena pasien usia tersebut memiliki cadangan fisiologis dan imun menurun yang lebih rendah daripada usia dewasa muda ${ }^{19}$. Fungsi sistem imunitas tubuh (immunocompetence) menurun sesuai umur. Kemampuan imunitas tubuh melawan infeksi menurun termasuk kecepatan respon imun dengan peningkatan usia. Hal ini bukan berarti manusia lebih sering terserang penyakit, tetapi saat menginjak usia tua maka resiko kesakitan meningkat seperti penyakit infeksi, kanker, kelainan autoimun, atau penyakit kronik. Hal ini disebabkan oleh perjalanan alamiah penyakit yang berkembang secara lambat dan gejala-gejalanya tidak terlihat sampai beberapa tahun kemudian. Di samping itu, produksi imunoglobulin yang dihasilkan oleh tubuh lansia juga berkurang jumlahnya sehingga vaksinasi yang diberikan pada kelompok lansia kurang efektif melawan penyakit. Masalah lain yang muncul adalah tubuh lansia kehilangan kemampuan untuk membedakan benda asing yang masuk ke dalam tubuh atau memang benda itu bagian dari dalam tubuhnya sendiri ${ }^{3}$. Berdasarkan data yang didapatkan di Amerika Serikat, lebih dari setengah pasien di ICU adalah pasien usia dengan 65 tahun ke atas dengan diagnosa penyakit kritis seperti sepsis. Sepsis terbukti menjadi ancaman bagi pasienpasien geriatri. Berdasarkan penelitian sebelumnya, pasien dengan umur 65 tahun dan lebih memiliki angka mortalitas sepsis yang tinggi dibandingkan dengan pasien yang lebih muda. Insiden sepsis meningkat tajam di usia dewasa-tua, 65 tahun dengan $27.7 \%$ 15 .
Berdasarkan karakteristik pasien dengan kelompok pendidikan menunjukkan bahwa pendidikan SD memiliki persentase sebesar 46,67\%. Dengan semakin tinggi pendidikan seseorang, makin tinggi pula kesadaran tentang hak yang dimilikinya, hal ini akan meningkatkan tuntutan terhadap hak untuk memperoleh informasi, hak untuk menolak/menerima pengobatan yang ditawarkan ${ }^{12}$.

Berdasarkan karakteristik pasien dengan kelompok pekerjaan menunjukkan bahwa pekerjaan IRT (ibu rumah tangga) memiliki persentase sebesar 46,67\%. Hal ini menunjukkan karena tanggung jawab dan tugas perempuan (IRT) adalah mengelola rumah tangga, mengasuh dan merawat anak. Ibu rumah tangga yang tidak bekerja lebih banyak waktu dirumah, sehingga kurangnya beraktifitas, seperti kurangnya berolahraga yang bisa menurunkan kekebalan sistem imun tubuh, hal ini dapat memicu terjadinya sepsis ${ }^{7}$.

Pasien sepsis di instalasi rawat inap dibeberapa rumah sakit periode JanuariDesember 2017 didapatkan bakteri gram negatif dengan persentase $70 \%$ dan gram positif dengan persentase $30 \%$. Hasil jenis bakteri penginfeksi sepsis disajikan pada Tabel 2.

Berdasarkan bakteri yang menginfeksi sepsis, maka dapat disimpulkan bahwa yang paling banyak menyebabkan sepsis adalah bakteri gram negatif. Bakteri gram negatif merupakan mikroorganisme patogen rumah sakit yang terbesar. Patogen ini dapat resisten terhadap antibiotik $\beta$-Laktam melalui berbagai mekanisme resistensi ${ }^{4}$. Penyebab bakteri terbesar pada sepsis adalah bakteri gram negatif diberbagai kasus, yang menghasilkan berbagai macam produk yang dapat menstimulasi sel imun. Sel tersebut kemudian dipacu untuk melepaskan mediator inflamasi. Produk yang berperan penting dalam sepsis adalah lipopolisakarida (LPS). LPS 
berfungsi merangsang peradangan pada jaringan, demam dan syok pada pasien yang terinfeksi. Struktur LPS bertanggung jawab terhadap reaksi dalam tubuh penderita. LPS tidak mempunyai sifat toksik, tetapi merangsang pengeluaran mediator inflamasi yang bertanggung jawab terhadap sepsis. Kemudian bakteri gram positif, yaitu
Sthaphylococcus,

Pneumococcus, Streptococcus, dan bakteri gram positif lainnya jarang menyebabkan sepsis, dengan angka kejadian 20\%-40\% dari keseluruhan kasus. Pada sepsis sel-sel imun yang paling terlihat mengalami disregulasi apoptosis adalah limfosit, hilangnya limfosit ini akan menurunkan survival sepsis ${ }^{8}$.

Tabel 2 Jenis Bakteri Penginfeksi

\begin{tabular}{lcc}
\hline \multicolumn{1}{c}{ Nama Bakteri } & Jumlah (n) & Persentase (\%) \\
\cline { 1 - 1 } 1. Gram Negatif & & \\
\cline { 1 - 2 } Eschericia colli & 6 & 20 \\
Acinetobacter baumanni & 5 & 16,67 \\
Serratia marcescens & 3 & 10 \\
Klebsiella pneumoniae & 3 & 10 \\
Morganella morgini & 2 & 6,67 \\
Pseudomonas aeruginosa & 1 & 3,33 \\
Proteus vulgaris & 1 & 3,33 \\
\hline Jumlah & 20 & 70 \\
\hline 2. Gram Positif & & \\
Staphylococcus aureus & 4 & 13,33 \\
Staphylococcus hominis & 2 & 6,67 \\
Sreptococcus anginosus & 1 & 3,33 \\
Staphylococcus epidermis & 1 & 3,33 \\
Staphylococcus haemolyficus & 1 & 3,33 \\
\hline Jumlah & 10 & 33,33 \\
\hline & 30 & 100 \\
\hline
\end{tabular}

Tabel 3 Pola Penggunaan Pemilihan Antibiotik Empiris

\begin{tabular}{|c|c|c|c|}
\hline Golongan Antibiotik & Jenis Antibiotik & Jumlah & Persentase $(\%)$ \\
\hline \multirow[t]{2}{*}{ Sefalosporin } & Ceftriaxone & 14 & 46,67 \\
\hline & Cefoperazone & 4 & 13,33 \\
\hline Karbapenem & Meropenem & 7 & 23,33 \\
\hline \multirow{2}{*}{ Flurokuinolon } & Levofloxacin & 2 & 6,67 \\
\hline & Ciprofloxacin & 2 & 6,67 \\
\hline \multirow[t]{2}{*}{ Glukopeptida } & Vancomycin & 1 & 3,33 \\
\hline & Jumlah & 30 & 100 \\
\hline \multicolumn{4}{|c|}{ Durasi Pemberian } \\
\hline \multicolumn{2}{|c|}{ Waktu Penggunaan ( < 7 Hari) } & 11 & 40 \\
\hline \multicolumn{2}{|c|}{ Waktu Penggunaan ( 7 Hari) } & 9 & 30 \\
\hline \multicolumn{2}{|c|}{ Waktu Penggunaan ( > 7 Hari) } & 9 & 30 \\
\hline & Jumlah & 30 & 100 \\
\hline
\end{tabular}


Tabel 4 Sensitivitas dan Resistensi Bakteri dari Hasil Kultur Terhadap Antibiotik

\begin{tabular}{|c|c|c|c|c|c|c|c|c|c|c|c|c|c|c|c|c|c|c|}
\hline \multirow{3}{*}{$\begin{array}{l}\text { Bakteri Hasil } \\
\text { Kultur }\end{array}$} & \multicolumn{18}{|c|}{ Jenis Antibiotik } \\
\hline & \multicolumn{3}{|c|}{$\mathrm{CF}$} & \multicolumn{3}{|c|}{ MPM } & \multicolumn{3}{|c|}{ LV } & \multicolumn{3}{|c|}{$\mathrm{CP}$} & \multicolumn{3}{|c|}{$\mathrm{CZ}$} & \multicolumn{3}{|c|}{$\mathrm{VC}$} \\
\hline & $\mathrm{S}$ & $\mathrm{I}$ & $\mathrm{R}$ & $\mathrm{S}$ & $\mathrm{I}$ & $\mathrm{R}$ & $\mathrm{S}$ & $\mathrm{I}$ & $\mathrm{R}$ & $\mathrm{S}$ & I & $\mathrm{R}$ & $\mathrm{S}$ & I & $\mathrm{R}$ & $\mathrm{S}$ & I & $\mathrm{R}$ \\
\hline E.coli & 3 & - & - & 2 & - & - & 1 & - & - & - & - & - & - & - & - & - & - & - \\
\hline A.baumanni & - & 1 & 2 & 1 & - & - & - & - & - & - & - & - & 1 & - & - & - & - & - \\
\hline S.marcesnens & 2 & 1 & - & - & - & - & - & - & - & - & - & - & - & - & - & - & - & - \\
\hline K.pneumoniae & - & - & 2 & 1 & - & - & - & - & - & - & - & - & - & - & - & - & - & - \\
\hline M.morgini & - & - & - & - & - & - & - & - & - & - & - & - & 2 & - & - & - & - & - \\
\hline P.aeruginosa & - & - & - & - & 1 & - & - & - & - & - & - & - & - & - & - & - & - & - \\
\hline P.vulgaris & - & - & - & 1 & - & - & - & - & - & - & - & - & - & - & - & - & - & - \\
\hline S.aureus & 1 & - & - & 1 & - & - & 1 & - & - & - & - & - & - & - & - & 1 & - & - \\
\hline S.hominis & - & - & - & - & - & - & - & - & - & 2 & - & - & - & - & - & - & - & - \\
\hline S.anginosus & 1 & - & - & - & - & - & - & - & - & - & - & - & - & - & - & - & - & - \\
\hline S.epidermis & 1 & - & - & - & - & - & - & - & - & - & - & - & - & - & - & - & - & - \\
\hline S.haemolyficus & - & - & - & - & - & - & - & - & - & - & - & - & 1 & - & - & - & - & - \\
\hline
\end{tabular}

Keterangan : 'S' Sensitifitas, 'I' Intermediate, 'R' Resistensi, (-) tidak ada data.

$\mathrm{CF}=$ Ceftriaxone, $\mathrm{MPM}=$ Meropenem, $\mathrm{LV}=$ Levofloxacin, $\mathrm{CP}=$ Ciprofofloxacin, $\mathrm{CZ}=$ Cefoperazone, $\mathrm{VC}=$ Vancomycin

Berdasarkan pola penggunaan pemilihan antibiotik empiris didapatkan bahwa antibiotik golongan Sefalosporin dengan jenis antibiotik ceftriaxone paling banyak digunakan, yaitu 14 pasien $(46,67 \%)$ dan golongan Karbapenem dengan jenis antibiotik Meropenem, yaitu 7 pasien $(23,33 \%)$. Pemilihan antibiotika berdasarkan data empiris, oleh karenanya harus secepatnya diberikan. Antibiotik yang diberikan, yaitu Ceftriaxone dan Meropenem diharapkan mempunyai afinitas tinggi dengan kuman penyebabnya, sehingga dapat membunuh semua mikroorganisme penyebab baik gram positif maupun negatif. Antibiotik yang diberikan berspektrum luas dan mepunyai efek bakterisidal cepat. Antibiotika yang biasanya diberikan secara empiris adalah Cefalosporin generasi III karena memiliki efek terhadap bakteri gram positif dan negatif. Juga dapat diberikan Cefalosporin dengan kombinasi $\quad \beta$-laktam ${ }^{5}$. Ceftriaxone mempunyai spektrum aktivitas yang luas bekerja dengan menghambat sintesa dinding sel mikroba dan merupakan salah satu antibiotik yang tidak menstimulusi pelepasan lipopolisakarida sehingga tidak memperburuk keadaaan pasien ${ }^{7}$. Disamping itu, Karbapenem disarankan untuk terapi antibiotik yang resisten kebanyakan patogen. Meropenem aktivitasnya lebih besar terhadap aerob gram negatif dan aktivitasnya pada grampositif lebih kecil. Secara signifikan obat ini tidak mengalami degradasi oleh dehidropeptidase ginjal. Dosis buat dewasa 1 gram tiap 8 jam, namun harus dikurangi untuk pasien dengan bersihan kreatinin kurang dari $50 \mathrm{ml} /$ menit. Karbapenem pilihan untuk terapi infeksi Enterobacter, karena kekebalannya terhadap penghancuran oleh $\beta$-laktam yang diproduksi oleh organismeorganisme ini. Selain itu juga aktif terhadap strain pneumokokkus yang resisten penisilin ${ }^{9}$.

Menurut Kentjono (2005) untuk mencegah agar sepsis tidak jatuh dalam syok septis sebaiknya diberikan paling tidak dua obat, yaitu diantara antibiotika $\beta$-laktam selektif high molecular weight (HMW), aminoglikosida dan fluorokuinolon. Terapi antibiotika empiris yang diberikan adalah yang 
berspektrum luas, bersifat bakterisidal, dengan dosis yang dapat mencapai kadar yang cukup (therapeutic level). Dan berdasarkan durasi pemberian kurang dari 7 hari ( $<7$ hari) untuk mengkonsumsi antibiotik empirik, karena antibiotik empiris diberikan yaitu 48-72 jam (35hari), maka jangka waktu pemberian harus cukup, selama 7-14 hari, lebih lama bila ada infeksi persisten penyebab bakteremia ${ }^{16}$.

Berdasarkan hasil pengujian sensitivitas dan resistensi antibakteri, menunjukkan bahwa adanya bakteri yang resisten terhadap antibiotik, yaitu Ceftriaxone pada bakteri A.baumani dan K.pneumoniae. Hasil uji resistensi yang dilakukan terhadap bakteri $K$. pneumoniae, bakteri ini mengalami resistensi yang tinggi terhadap antibiotik Ceftriakson. Bakteri K.pneumoniae merupakan bakteri yang menghasilkan enzim ESBL (Extended Spectrum Beta Lactamase), enzim ini dapat merusak cincin $\beta$-laktam dan menimbulkan resistensi terhadap antibiotik golongan $\beta$ laktam seperti penisilin dan sefalosporin ${ }^{6}$. Tetapi Ceftriaxone juga masih sensitif dibeberapa bakteri. Kemudian pada tahun 2008, Meropenem Yearly Susceptibility Test information Collection (MYSTIC) melaporkan kepekaan bakteri patogen terhadap meropenem adalah Pseudomonas aeruginosa, Enterobacteriaceae, Streptococcus pneumonia, Acinetobacter spp ${ }^{13}$.

Tabel 5 Ketepatan Pemilihan Antibiotik Empiris Ceftriaxone dan Meropenem

\begin{tabular}{ccccc}
\hline Antibiotik & Jumlah & \multicolumn{3}{c}{ Hasil Kultur } \\
\cline { 3 - 5 } Empiris & Penggunaan (n) & Sensitif (\%) & Intermediate $(\%)$ & Resisten $(\%)$ \\
\hline Ceftriakson & 14 & $8(26,67)$ & $2(6,66)$ & $4(13,3)$ \\
Meropenem & 7 & $5(16,67)$ & $1(3,33)$ & $1(3,33)$ \\
\hline
\end{tabular}

Tabel 6 Hubungan Ketepatan Pemilihan Antibiotik Empiris dengan Outcome Terapi

\begin{tabular}{lccc}
\hline & \multicolumn{3}{c}{ Chi-Square Tests } \\
\hline & Value & df & Asymptotic Significance (2-sided) \\
\cline { 2 - 4 } Pearson Chi-Square & $17,536^{\mathrm{a}}$ & 5 &, 004 \\
Likelihood Ratio & 19,352 & 5 &, 002 \\
Linear-by-Linear Association &, 003 & 1 &, 955 \\
N of Valid Cases & 30 & & \\
\hline
\end{tabular}

Berdasarkan ketepatan pemilihan antibiotik empiris menunjukkan Ceftriakson dan Meropenem masih sensitif, dengan hasil Ceftriakson persentase sensitif $(26,67 \%)$ intermediate $(6,67 \%)$ dan resisten $(13,3 \%)$ dan Meropenem persentase sensitif $(16,67 \%)$, intermediate $(3,33 \%)$ dan resisten $(3,33 \%)$. Maka diperoleh ketepatan pemilihan antibiotik empiris yaitu 61,90\%. Sensitifitas adalah kemampuan zat antibiotik untuk menghambat pertumbuhan bakteri in vitro dengan dosis antibiotik yang dianjurkan. Dengan tepatnya pemilihan antibiotik ini maka resiko resisten antibiotik akan rendah. Pemberian antibiotik hendaknya disesuaikan dengan bakteri yang ada pada masing-masing unit perawatan ${ }^{17}$, karena dengan tepatnya penggunaan antibiotik akan mengurangi resiko resisten antibiotik. 
Berdasarkan hubungan ketepatan pemilihan antibiotik empiris dengan outcome terapi pada pasien sepsis terlihat nilai Asimp.Sig sebesar 0,004, karena nilai Asimp.Sig $p<0,05$, maka dapat disimpulkan bahwa adanya hubungan yang signifikan antara antibiotik empiris dengan outcome terapi. Hal ini dapat diartikan bahwa antibiotik yang digunakan mempunyai korelasi dengan outcome yang diperoleh. Dengan tepatnya pemilihan antibiotik ini dapat menghambat atau memperlambat proses perkembangan penyakit, sehingga dapat mengantisipasi terjadinya komplikasi dengan penyakit lain dan meningkatkan atau mencapai kualitas hidup pasien yang lebih baik $^{1}$. Ketepatan pemilihan obat tersebut bertujuan agar penggunaan obat sebagai tanggung jawab bersama dapat menghasilkan outcome terapi yang optimal $^{11}$.

\section{KESIMPULAN}

Berdasarkan hasil penelitian yang telah dilakukan, maka dapat kesimpulan bahwa :

1. Karakteristik pasien berdasarkan kelompok jenis kelamin adalah perempuan 56,67\%, dan laki-laki sebanyak 43,33\%. Kelompok Usia yang paling banyak didiagnosa sepsis adalah usia 56-65 tahun sebesar $46,67 \%$. Kelompok pendidikan yang paling banyak didiagnosa sepsis adalah pendidikan SD $46,67 \%$ dan pekerjaan yang paling banyak didiagnosa sepsis adalah ibu rumah tangga (IRT) 47,67\%.

2. Bakteri penginfeksi pada sepsis yang terbanyak adalah bakteri gram negatif dengan persentase $70 \%$ dan bakteri gram positif dengan persentase $30 \%$.

3. Pola penggunaan pemilihan antibiotik empiris yang digunakan adalah Ceftriaxone 46,67\%, dan Meropenem $23,33 \%$.

4. Sensitivitas dan resistensi bakteri berdasarkan bakteri penginfeksi antibiotik yang masih sensitif adalah
Ceftriaxone nilai persentase sensitif $(26,67 \%)$ intermediate $(6,67 \%)$ dan resisten (13,3\%) dan Meropenem nilai persentase sensitif (16,67\%), intermediate $\quad(3,33 \%) \quad$ dan resisten(3,33\%).

5. Ketepatan pemilihan antibiotika empiris yang sesuai dengan hasil kultur dengan nilai persentase $61,90 \%$.

6. Hubungan ketepatan pemilihan antibiotik empiris dengan outcome terapi pada pasien menunjukkan hasil adanya hubungan yang signifikan, dengan nilai Asimp.Sig yaitu 0,004 $(\mathrm{p}<0,05)$.

\section{UCAPAN TERIMA KASIH}

Penulis mengucapkan terima kasih kepada pihak rumah sakit khususnya pada bagian rekam medis atas bantuan dalam perolehan data.

\section{DAFTAR PUSTAKA}

[1] ASHP Board of Directors, April 21, 1993. ASHP House of Delegates. Developed by the ASHP Council on Professional Affairs.

[2] Dewi, R., 2011. Sepsis Pada Ana : Pola Kuman dan Uji kepekaan. Majalah Kedokteran Indonesia, 61 (3): 101-106.

[3] Fatmah. 2006. Respons Imunitas Yang Rendah Pada Tubuh Manusia Usia Lanjut. Departemen Gizi Kesehatan Masyarakat, Fakultas Kesehatan Masyarakat, Universitas Indonesia, Depok 16424, Indonesia. Makara, Kesehatan, Vol. 10, No. 1:47-53.

[4] Glauser MP, Zanetti G, Baumgartner JD, Cohen J. 1991. Septic Shock: Pathogenesis. Lancet, 338: 732-736.

[5] Guntur. 2006, 'Sepsis' dalam : SIRS \& Sepsis (Imunologi, Diagnosis, Penatalaksanaan), ed., D.A. Prasetyo, Y.S. Sutanto. Sebelas Maret University Press. Surakarta, hal. 1-13.

[6] Herwana E, Yenny, Pudjiaji L, Surjawidjaja J, Murad Lesmana. 
2008. Prevalence Of Extended Spectrum Beta-Lactamase In Klebsiella Pneumonia. Jurnal Universa Medicina.

[7] Hidayati, Helmi Arifin dan Raveinal. 2016. Study of Antibiotic Using on Septic Patients with Kidney Disorder. Fakultas Farmasi, Universitas Andalas. Jurnal Sains Farmasi \& Klinis , 2(2), 129-137.

[8] Hotchkiss RS, Swanson PE, Freeman BD, Tin-sley KW, Cobb JP, Matuschak GM. Apoptotic cell death in patients with sepsis, shock, and multiple organ dysfunction. Crit Care Med. 1999; 27(7):1230-51.

[9] Katzung G. Bertram. 2008. Farmakologi Dasar dan Klinik (Edisi 8). Alih bahasa oleh Bagian Farmakologi Fak. Kedokteran Univ. Airlangga. Salemba Medika. Jakarta.

[10]Kemenkes RI. 2011. Pedoman Umum Penggunaan Antibiotik. Jakarta.

[11] Kusumadewi, S., Anis, F. dan Endang, B., 2011. Peranan Teknologi Informasi dan Komunikasi di Bidang Obat dan Pengobatan dalam Mendukung Perlindungan Pasien. Halaman 40-44. Graha Ilmu. Yogyakarta.

[12] Notoatmodjo, S. 2007. Pendidikan dan Perilaku kesehatan.Cetakan 2. PT. Rineka Cipta. Jakarta.

[13]Rhomberg PR, and Jones RN. 2009. Summary trends for the Meropenem Yearly Susceptibility Test Information Collection Program: A 10-year experience in the United States (1999-2008). Diagn Microbiol Infect Dis.65(4):414-26. doi: 10.1016/j.diagm icrobio.2009.08.020.

[14]Sakr Y, Elia C, Mascia L, Barberis B, Cardellino S, Livigni S, Fiore G, Filippini C, Ranieri VM. 2013. The Influence of Gender on The Epidemiology Of And Outcome From Severe Sepsis. Critical Care.17(R50).

[15] Starr M, and Saiyo H. 2014. Sepsis In Old Ages: Review Of Human and Animal Studies.

[16] Suharto. 2000. Tatalaksana Syok Septik dalam : Update on Shock. Pertemuan Ilmiah Terpadu I, ed.Suharto, A. Aadi, N.M. Rehatta, T. Ontoseno. Fakultas Kedokteran Universitas Airlangga. Surabaya, hal. 173-186.

[17]Tiflah. 2006. Bakteremia pada Neonatus: Hubungan Pola Kuman dan Kepekaan terhadap Antibiotik Inisial serta Faktor Risikonya di Bangsal Bayi Risiko Tinggi (BBRT) RS. DR. Kariadi Tahun 2004. Skripsi, Fakultas Kedokteran, Universitas Diponegoro Semarang.

[18] Tony Yu, Edgar Black, Kenneth E Sands, J Sanford Schwartz, Patricia L Hibberd, Paul S Graman, Paul N Lanken, Katherine L Kahn, David R Snydman, Jeffrey Parsonnet, Richard Moore, Richard Platt and David W Bates. 2003. Severesepsis: variation in resourceand therapeutic modality use among academic centers. Critical Care 7(3):R24- R34

[19] Vera, Evacuasinya Endang, dan Richardo Yuvens. 2011. Karakteristik Pasien Usia Lanjut di Ruang Rawat Intensif Rumah Sakit Immanuel Bandung. Jurnal JKM.10:110-119. 